\title{
Perancangan Instrumen Tes Literasi Kimia Pada Materi Asam dan Basa
}

\section{Designing Chemical Literacy Test Instrumentation of Acid and Base Topic}

\author{
A Wahyuni ${ }^{1}$ and E Yusmaita ${ }^{1 *}$ \\ 1 Pendidikan Kimia, Universitas Negeri Padang, Jl. Prof. Dr. Hamka, Air Tawar Barat, \\ Padang Utara, Sumatera Barat, Indonesia 25171 \\ *ekayusmaita@fmipa.unp.ac.id
}

\section{ARTICLE INFO}

Received 04 June 2020

Revised 16 June 2020

Published 03 July 2020

\begin{abstract}
Designing chemical literacy test instrumentation of acid and base topic is carried out to help develop student's chemical literacy abilities that are beneficial to life. The purposed of this research is to describe the stages of designing questions using Model of Educational Reconstruction and describing the value of the content validity of chemical literacy questions on acid and base topic. The research's type is to development with MER design. The content validity test conducted by 3 validates. The research instrument used was a question of chemical literacy in acid and base topic totaling 9 discourse questions which were elaborated in 15 item questions. The data obtained were processed using the Aiken's V formula. The result showed that the instrument's content validity considered as valid.
\end{abstract}

\section{KEYWORDS}

Acid and Base, Chemical Literacy, Model of Educational Reconstruction

\begin{abstract}
ABSTRAK
Perancangan instrumen tes literasi kimia pada materi asam dan basa dilakukan untuk membantu mengembangkan kemampuan literasi kimia peserta didik yang bermanfaat bagi kehidupan. Tujuan dari penelitian ini adalah menjabarkan tahapan perancangan soal dengan menggunakan Model of Educational Reconstruction dan mendeskripsikan nilai validitas konten soal literasi kimia pada materi asam dan basa. Jenis penelitian ialah pengembangan dengan desain MER. Uji validitas konten dilakukan oleh 3 validator. Instrumen penelitian yang digunakan yaitu soal literasi kimia pada materi asam dan basa sebanyak 9 wacana soal yang dijabarkan dalam 15 butir item soal. Data yang diperoleh diolah dengan rumus Aiken's V. Hasil penelitian menunjukkan bahwa instrumen yang dihasilkan memiliki validitas konten dengan kategori valid.
\end{abstract}

KATA KUNCI

Asam dan Basa, Literasi Kimia, Model of Educational Reconstruction 


\section{PENDAHULUAN}

Penilaian merupakan kegiatan penting dalam proses pembelajaran sehingga harus direncanakan dengan baik. Salah satu hal yang perlu dilakukan sebelum melakukan penilaian adalah penyediaan instrumen penilaian. Instrumen penilaian yang baik dan memenuhi standar dapat mengungkap kemampuan peserta didik dari segi apa yang diketahui, dipahami, dan dilakukan oleh peserta didik ${ }^{[1]}$.

Program for International Student Assessment (PISA) merupakan program penilaian yang dilaksanakan oleh Organization for Economic Co-operation and Development (OECD) yang melaksanakan penilaian tiga tahunan sejak tahun 2000. Penilaian dilakukan untuk mengetahui tingkat literasi peserta didik pada beberapa bidang salah satunya dalam bidang sains. Data PISA tahun 2018 menunjukkan tingkat literasi peserta didik Indonesia berada pada tingkat 10 terbawah yaitu peringkat 70 dari 78 negara peserta ${ }^{[2]}$.

Beberapa faktor rendahnya tingkat literasi sains peserta didik Indonesia antara lain proses pembelajaran yang ada belum memfasilitasi literasi sains peserta didik, peserta didik belum terbiasa dalam menyelesaikan tes atau soal yang berbasis literasi sains serta proses pengevaluasian pembelajaran yang belum dapat mengembangkan kemampuan literasi sains peserta didik ${ }^{[3]}$. Hal ini disebabkan karena masih terbatasnya soal-soal berbasis literasi sains ${ }^{[4]}$.

Ilmu kimia termasuk dalam rumpun sains, sehingga literasi kimia merupakan bagian dari literasi sains ${ }^{[5]}$. Literasi kimia mengacu pada kemampuan seseorang dalam memahami dan menerapkan pengetahuan kimia dalam kehidupan sehari-hari. Dalam hal ini terdapat tiga aspek utama yaitu memahami aspek pengetahuan, kesadaran, dan penerapan kimia dalam kehidupan sehari-hari secara tepat dan efektif ${ }^{[6]}$.

Literasi kimia berhubungan dengan bagaimana peserta didik dapat menghargai alam dengan memanfaatkan sains/ilmu kimia dan teknologi yang dikuasainya ${ }^{[7]}$. Orang yang memiliki literasi kimia memahami konsep dasar kimia, dapat menjelaskan fenomena dan menyelesaikan masalah dalam kehidupan dengan menggunakan pemahamannya tentang kimia, memahami inovasi kimia dalam kehidupan sosial seperti pentingnya aplikasi obat-obatan, pupuk, serta memiliki minat terhadap kimia. Terdapat beberapa muatan aspek pada literasi kimia, yaitunya aspek konten, konteks, Higher Order Learning Skills (HOLS) dan aspek sikap ${ }^{[8]}$.

Salah satu cara yang dapat dilakukan untuk membantu peserta didik dalam mengembangkan kemampuan literasi kimia adalah memberikan evaluasi kepada peserta didik berupa instrumen soal yang berbasis literasi kimia ${ }^{[9]}$. Instrumen soal ini dilengkapi dengan wacana kontekstual meliputi isu personal, lokal, nasional, dan global yang membahas tentang keilmuan sains, teknologi, energi, kesehatan dan pangan. Di samping itu, literasi kimia juga mengandung muatan pengetahuan konten, pengetahuan prosedural, dan sikap yang ditunjukkan dari minat terhadap sains, teknologi, dan peduli lingkungan ${ }^{[10]}$.

Perancangan asesmen literasi kimia bertujuan agar peserta didik melek literasi kimia. Dengan adanya asesmen literasi kimia yang valid dan reliabel diharapkan mampu memberikan gambaran kemampuan literasi peserta didik dalam menjawab soal ${ }^{[11]}$. Instrumen soal literasi kimia yang dirancang berdasarkan aspek literasi kimia, diharapkan dapat memperoleh gambaran tingkatan literasi kimia peserta didik berdasarkan level literasi kimia ${ }^{[12]}$.

Oleh sebab itu, diperlukan suatu instrumen tes literasi kimia yang dapat mengukur dan membantu mengembangkan literasi kimia peserta didik. Perancangan instrumen tes literasi kimia yaitu pada materi asam dan basa. Hal ini dikarenakan materi asam dan basa memenuhi prinsip dasar pemilihan konten pada PISA, yaitu materi asam dan basa relevan dan banyak ditemui dalam kehidupan sehari-hari. Selain itu, materi asam dan basa tidak hanya berupa konsep tetapi juga terdapat keterampilan proses di dalamnya ${ }^{[13]}$. Sehingga dirancanglah instrumen tes literasi kimia pada materi asam dan basa.

\section{METODE}

Jenis penelitian ini adalah pengembangan dengan desain penelitian Model of Educational Reconstruction (MER). Ide dasar yang dikembangkan dalam model penelitian ini adalah struktur konten terlebih dahulu direkonstruksi sesuai dengan tujuan pembelajaran kognitif dan afektif, setelah itu baru dapat digunakan dalam pengajaran ${ }^{[14]}$.

Penelitian menggunakan 2 tahapan mendasar dari 3 tahapan yang terdapat pada MER, tahapan tersebut adalah analisis struktur konten dan penyelidikan empiris. Tahapan analisis struktur konten dilakukan melalui analisis literatur, mencakup analisis silabus, analisis konten, dan analisis konteks. Pada tahap penyelidikan empiris dilakukan uji validitas konten oleh Subject Matter Expert (SME).

Uji validitas konten dilakukan oleh 2 dosen kimia FMIPA UNP dan 1 guru kimia. Instrumen penelitian yang digunakan yaitu lembar validasi konten soal literasi kimia. Penilaian dilakukan dengan memberikan angka antara 1 (yaitu tidak relevan atau tidak valid) sampai dengan 5 (yaitu sangat relevan atau sangat valid). Data hasil validasi diolah menggunakan rumus Aiken's V.

$$
V=\frac{\sum s}{n(c-1)}
$$

Keterangan :

$\mathrm{V}=$ skala Aiken

$\mathrm{s}=\mathrm{r}-\mathrm{lo}$

$\mathrm{n}=$ jumlah validator

$\mathrm{r}=$ angka yang diberikan oleh validator

lo = angka penilaian yang terendah (dalam hal ini = 1)

c = angka penilaian yang tertinggi (dalam hal ini $=5$ ) 
Kriteria penilaian penerimaan instrumen tes berdasarkan skala Aiken's V dapat dilihat pada Tabel 1 .

Tabel 1. Validitas berdasarkan skala Aiken's V ${ }^{[15]}$.

\begin{tabular}{c|c} 
Skala Aiken's V & Validitas \\
\hline $\mathrm{V} \leqslant 0,4$ & Kurang \\
\hline $0,4<\mathrm{V} \leqslant 0,8$ & Sedang \\
\hline $0,8<\mathrm{V}$ & Valid
\end{tabular}

\section{HASIL DAN DISKUSI}

\subsection{Analisis Struktur Konten}

Pada tahap analisis struktur konten diperoleh hasil berupa analisis silabus, analisis konten dan analisis konteks. Ketiga data tersebut merupakan dasar dalam penyusunan kisi-kisi soal dan kartu soal. Hasil pada tahap ini dijelaskan sebagai berikut.

\subsubsection{Analisis Silabus}

Analisis silabus pada materi Asam dan Basa kelas XI SMA/MA menggunakan silabus kimia kurikulum 2013. Pada tahap analisis silabus dilakukan penurunan Indikator Pencapaian Kompetensi (IPK) dari Kompetensi Dasar (KD) pada materi Asam dan Basa. Hasil analisis KD, diperoleh enam IPK pada materi asam dan basa.

\subsubsection{Analisis Konten}

Analisis konten yaitu analisis terhadap materi pokok asam dan basa yang dilakukan dengan menggunakan beberapa buku kimia universitas. Buku universitas yang digunakan tersebut adalah buku kimia dasar karangan Raymond Chang, Petrucci, Syukri, S., dan Jespersen. Tujuan dari tahapan ini adalah untuk mengonfirmasi kebenaran konsep sains dan struktur konten dari sudut pandang keilmuan sains. Analisis terhadap konten sains diperlukan karena beberapa buku teks sains menyajikan pengetahuan ilmiah yang abstrak dan beberapa istilah sains terjadi miskonsepsi pada peserta didik dalam kehidupan sehari-hari ${ }^{[14]}$.

\subsubsection{Analisis Konteks}

Analisis konteks yaitu penerapan konteks asam dan basa yang terdapat dalam kehidupan sehari-hari. Tujuan tahapan ini adalah bagaimana menghubungkan konten asam dan basa dengan aktivitas kontekstual/isu yang berkembang. Analisis konteks dilakukan dengan menggunakan jurnal/ artikel ilmiah. Contohnya, pada konsep asam menurut Arrhenius konteks dalam kehidupan yaitu asam semut, perolehan konteks ini dikutip pada artikel ilmiah ${ }^{[16]}$.

\subsubsection{Kisi-Kisi Soal}

Tahap selanjutnya pembuatan kisi-kisi soal. Kisi-kisi soal dibuat berdasarkan hasil analisis silabus, analisis konten, dan konteks. Pada kisi-kisi soal terdapat KD, IPK, indikator soal, level kognitif dan level pengetahuan berdasarkan pada taksonomi bloom, aspek literasi kimia yaitu aspek konten, konteks, HOLS, dan aspek sikap, bentuk soal (essay), serta nomor soal.

\subsubsection{Kartu Soal}

Kartu soal literasi kimia dibuat berdasarkan kisi-kisi soal dan memperhatikan aspek literasi kimia berupa aspek konten, konteks, HOLS, dan aspek sikap. Pada kartu soal memuat wacana soal, pertanyaan soal dan rubrik penilaian. Pada rubrik penilaian dilengkapi dengan jawaban soal, skor, dan level literasi kimia.

\subsection{Penyelidikan Empiris}

Tahapan penyelidikan empiris dilakukan uji validitas konten pada materi asam dan basa. Uji validitas konten dilakukan oleh 3 orang validator. Penyelidikan ini dilakukan untuk mengetahui sejauh mana kebenaran instrumen tes berdasarkan keilmuan pakar kimia, dalam hal ini dosen dan guru. Rancangan instrumen diharapkan dapat mewakili keseluruhan materi yang diujikan dan disesuaikan dengan kriteria. Hasil validitas konten dianalisis menggunakan rumus Aiken's V.

\subsection{Pembahasan}

Perancangan instrumen tes literasi kimia pada materi asam dan basa dengan model MER dilakukan dalam 2 tahap. Tahap pertama yaitu analisis struktur konten pada materi asam dan basa meliputi analisis silabus, analisis konten, analisis konteks, dan perancangan kisi-kisi soal, serta kartu soal literasi kimia. Tahap kedua adalah penyelidikan empiris.

Soal yang dirancang terdiri dari wacana, pertanyaan, dan jawaban soal, skor, serta rubrik penilaian. Dalam menentukan level literasi kimia pada soal sesuai dengan tuntutan indikator yang harus dicapai, setiap wacana soal akan memiliki level yang berbeda. Level literasi kimia ada lima, yaitu scientific illiteracy: pada level ini, peserta didik tidak dapat menjawab soal/jawaban yang diberikan salah; nominal scientific literacy: level di mana peserta didik dapat menjawab soal dengan singkat dan benar, tetapi terdapat miskonsepsi; functional scientific literacy: di mana peserta didik dapat menjawab soal dengan benar tetapi memiliki pemahaman yang terbatas; conceptual scientific literacy: di mana peserta didik dapat menjawab soal dengan benar dan dapat menghubungkannya dengan beberapa konsep; dan multidimensional scientific literacy: di mana peserta didik dapat menjawab soal dengan benar dan lebih luas lagi, serta dapat mengembangkan beberapa konsep sesuai perkembangan ilmu sains dan teknologi.

Pada materi asam dan basa ini, dirancang 9 wacana. Wacana pertama tentang asam formiat pada semut. Rubrik jawaban tertinggi pada soal pertama ini memperoleh skor 15 dan terdapat pada level conceptual scientific literacy. Pada wacana ini terdiri atas 1 butir item soal. Wacana kedua tentang pengapuran pada lahan pertanian, dengan skor tertinggi 15 dan juga terdapat pada level conceptual scientific literacy. Pada wacana ini terdiri atas 1 butir item soal Wacana ketiga tentang obat batuk, dengan skor tertinggi 15 pada level conceptual scientific literacy. Pada wacana ini terdiri atas 2 butir item soal. Wacana keempat tentang 
batu bara. Rubrik jawaban tertinggi memperoleh skor 15 pada level conceptual scientific literacy. Pada wacana ini terdiri atas 3 butir item soal.

Wacana kelima tentang asam cuka, dengan skor tertinggi 10 pada level functional scientific literacy. Pada wacana ini terdiri atas 2 butir item soal. Wacana keenam tentang pembersih berbahan amonia, dengan skor tertinggi 10 pada level functional scientific literacy. Pada wacana ini terdiri atas 3 butir item soal Wacana ketujuh tentang soda api, dengan skor tertinggi 15 pada level conceptual scientific literacy. Pada wacana ini terdiri atas 1 butir item soal. Wacana kedelapan tentang obat tetes mata, dengan skor tertinggi 15 pada level conceptual scientific literacy. Pada wacana ini terdiri atas 1 butir item soal. Wacana soal kesembilan tentang kunyit, dengan skor tertinggi 10 pada level functional scientific literacy. Pada wacana ini terdiri atas 1 butir item soal.

Empat komponen dari aspek literasi kimia yaitu aspek konten, merupakan konsep/materi asam dan basa yang terdapat pada soal, aspek konteks, merupakan penerapan konsep asam dan basa dalam kehidupan/mengangkatkan tema kontekstual sesuai isu yang berkembang, selanjutnya aspek High Order Learning Skills (HOLS), merupakan kemampuan mengidentifikasi pertanyaan, mencari informasi, memahami dan menganalisis permasalahan yang terjadi, serta aspek sikap ${ }^{[8]}$.

Rancangan soal literasi kimia terdiri atas 9 wacana soal dan 15 butir item soal. Beberapa contoh rancangan soal literasi kimia dapat dilihat pada Tabel 2 dan Tabel 3.

Indikator soal nomor 1 pada Tabel 2 yaitu disajikan wacana tentang asam semut (asam formiat), peserta didik dapat menjelaskan konsep Asam menurut Arrhenius. Pada soal terdapat aspek konten yaitu konsep Asam menurut Arrhenius yang dianalisis dengan menggunakan buku kimia universitas. Aspek konteks yaitu asam semut yang dianalisis dengan menggunakan artikel ilmiah.

Level literasi kimia paling tinggi pada soal ini berada pada level conceptual scientific literacy, dengan skor 15. Perolehan skor 15 pada level tertinggi tersebut artinya peserta didik dapat menjawab pertanyaan dan memberikan penjelasan yang benar mengenai konsep Asam menurut Arrhenius. Peserta didik dalam kategori level functional scientific literacy, artinya peserta didik dapat menjawab soal dengan benar tetapi penjelasan/pemahamannya masih terbatas. Posisi level nominal scientific literacy, artinya peserta didik dapat menjawab soal secara singkat. Level literasi kimia terendah yaitu scientific illiteracy, di mana peserta didik tidak dapat menjawab soal/jawaban yang diberikan salah. Berdasarkan hasil analisis validitas konten nilai validitas konten soal yaitu 0,775 pada kategori "sedang”. Suatu tes dikatakan valid apabila butir/isi yang terdapat dalam tes mampu mewakili secara keseluruhan konten yang diujikan/dapat mengukur yang hendak diukur. Sehingga soal ini dapat digunakan sebagai instrumen dalam mengukur tingkat literasi kimia peserta didik.
Tabel 2. Rancangan soal literasi kimia.

\section{Wacana soal}

No 1.

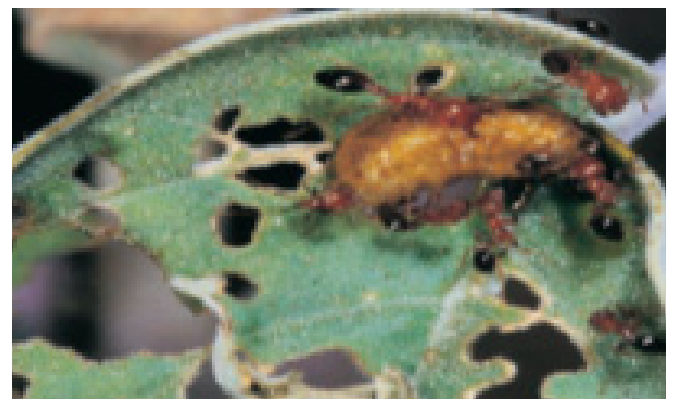

Gambar 1. Semut mengandung asam formiat ${ }^{[17]}$

Asam semut/asam formiat merupakan asam karboksilat yang paling sederhana dengan rumus molekul HCOOH. Nama asam formiat berasal dari kata Latin formica yang berarti semut. Semut menyemburkan asam formiat ketika sarangnya terancam, atau ketika adanya bahaya serangan dari luar. Asam formiat dapat larut dengan air. Reaksi ionisasi asam formiat dalam air sebagai berikut:

$\mathrm{HCHO}_{2}(a q)+\mathrm{H}_{2} \mathrm{O}(l) \rightleftarrows \mathrm{CHO}_{2}^{-}(a q)+\mathrm{H}_{3} \mathrm{O}^{+}(a q)$

\section{Pertanyaan soal}

Konsep asam menurut siapakah yang terdapat pada reaksi ionisasi asam formiat dalam air ? Jelaskan jawabanmu!

\section{Konteks}

\section{Jawaban soal}

Konsep asam menurut Arrhenius, karena asam formiat yang dalam air menghasilkan ion hidrogen $/ \mathrm{H}^{+}$.

Selanjutnya contoh rancangan soal literasi kimia pada soal nomor 2. Wacana pada soal ini tentang batu bara. Terdapat empat aspek literasi kimia pada soal yaitu aspek konten, aspek konteks, HOLS, dan aspek sikap. Rancangan soal beserta aspek literasi kimia dapat dilihat pada Tabel 3.

Soal nomor 2 pada Tabel 3, indikator soal yang disajikan adalah wacana tentang batu bara. Di sini, diharapkan peserta didik dapat menjelaskan konsep asam dan basa menurut Lewis, zat yang bertindak sebagai asam dan basa serta upaya yang dapat dilakukan untuk mengurangi dampak dari gas $\mathrm{SO}_{2}$ pada hujan asam. Pada soal ini terdapat aspek konten yaitu konsep asam dan basa menurut Lewis, aspek konteks yaitu batu bara, dan aspek sikap yaitu upaya yang dapat dilakukan untuk mengurangi dampak dari gas $\mathrm{SO}_{2}$ pada hujan asam.

Level literasi kimia yang paling tinggi pada soal nomor 2a berada pada level conceptual scientific literacy. Di sini, peserta didik dapat menjawab pertanyaan dan memberikan penjelasan yang benar mengenai konsep asam dan basa menurut Lewis. 
Tabel 3. Rancangan soal literasi kimia.

\section{Wacana soal}

No 2.

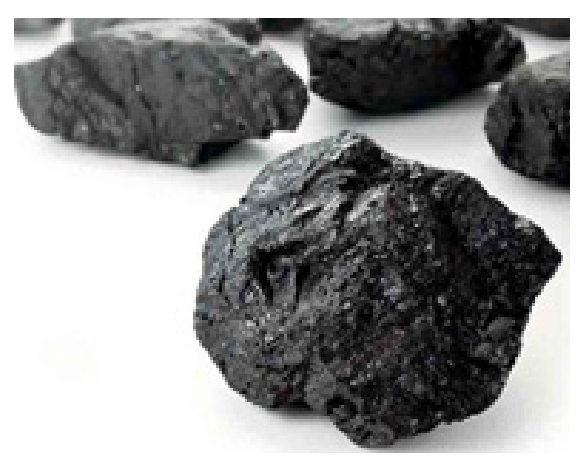

Gambar 2. Batu bara ${ }^{[18]}$

Batu bara digunakan sebagai bahan bakardalamindustri.Proses pembakaran dengan menggunakan batu bara menghasilkan gas buang, salah satunya gas sulfur dioksida $\left(\mathrm{SO}_{2}\right)$. Gas $\mathrm{SO}_{2}$ ini berbahaya bagi kesehatan dan mencemari lingkungan karena dapat menyebabkan hujan asam. Untuk itu, dilakukan upaya untuk mengurangi dampak dari gas $\mathrm{SO}_{2}$ yaitu dengan menambahkan batu kapur $\left(\mathrm{CaCO}_{3}\right)$ pada pembakaran batu bara. Saat proses pembakaran pada suhu tinggi $\mathrm{CaCO}_{3}$ terurai menjadi kapur (CaO). Kapur $\mathrm{CaO}$ inilah kemudian bereaksi dengan gas $\mathrm{SO}_{2}$ yang dihasilkan dari pembakaran batu bara. Berikut reaksi kapur $\mathrm{CaO}$ dengan gas $\mathrm{SO}_{2}$.

\section{Reaksi Kapur $\mathrm{CaO}$ dengan Gas $\mathrm{SO}_{2}$}

$\mathrm{CaO}(\mathrm{s})+\mathrm{SO}_{2}(\mathrm{~g}) \rightarrow \mathrm{CaSO}_{3}(\mathrm{~s})$

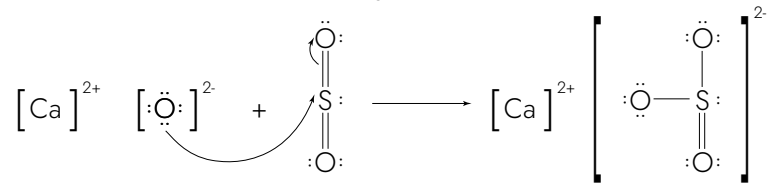

\section{Pertanyaan soal}

Berdasarkan persamaan reaksi $\mathrm{CaO}$ dan $\mathrm{SO}_{2}$,

a. Konsep Asam dan Basa menurut siapakah yang terdapat pada reaksi tersebut? Jelaskan jawabanmu!

b. Jelaskanlah zat yang bertindak sebagai Asam dan Basa!

c. Menurut ananda upaya apa yang dapat dilakukan untuk mengurangi dampak dari gas $\mathrm{SO}_{2}$ pada hujan asam?

\section{Jawaban soal}

a. Konsep Asam dan Basa menurut Lewis, karena terjadi serah terima pasangan elektron di mana $\mathrm{SO}_{2}$ menerima sepasang elektron sehingga bertindak sebagai Asam sedangkan $\mathrm{CaO}$ sebagai Basa karena memberi sepasang elektron.

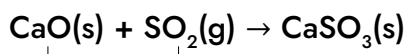

b.

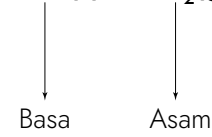

Zat yang bertindak sebagai Asam adalah $\mathrm{SO}_{2}$ karena $\mathrm{SO}_{2}$ menerima sepasang elektron. Sedangkan $\mathrm{CaO}$ bertindak sebagai Basa karena $\mathrm{CaO}$ memberi sepasang elektron.

c. Upaya yang dapat dilakukan untuk mengurangi dampak dari gas $\mathrm{SO}_{2}$ pada hujan asam, yaitu:

- Memakai bahan bakar dengan bijak.

- Tidakmenebang pohon sembarangan.

- Melakukan Reboisasi.

- Mengaplikasikan prinsip 3R (Reuse, Recycle, Reduce).

- Menggunakan berbagai peralatan yang ramah lingkungan.
Sementara, pada soal nomor $2 \mathrm{~b}$, level literasi kimia yang paling tinggi berada pada level functional scientific literacy. Pada level ini, peserta didik dapat menjawab soal dengan benar tetapi penjelasan/ pemahamannya masih terbatas pada konsep asam dan basa menurut Lewis. Sedangkan, pada soal 2c merupakan soal yang menanyakan sikap peserta didik dalam upaya mengurangi dampak gas $\mathrm{SO}_{2}$ pada hujan asam. Berdasarkan hasil analisis validitas konten nilai validitas konten soal yaitu 0,808 pada kategori "valid". Sehingga soal ini dapat digunakan dalam mengukur tingkat literasi kimia peserta didik.

Berdasarkan hasil uji validitas konten menggunakan rumus Aiken's V dari 9 wacana yang tersebar dalam 15 butir item soal yang telah dirancang, terdapat 3 soal pada kategori sedang dan 12 soal lainnya pada kategori valid. Rata-rata nilai validitas konten seluruh soal literasi kimia pada materi asam dan basa yang dirancang yaitu 0,804 pada kategori valid.

\section{SIMPULAN}

Perancangan instrumen soal literasi kimia pada materi asam dan basa pada penelitian ini menggunakan Model of Educational Reconstruction. Prosesnya terdiri atas 2 tahap, yaitu tahap analisis struktur konten dan penyelidikan empiris. Instrumen soal yang dihasilkan berupa 9 wacana soal yang tersebar dalam 15 butir item soal. Rata-rata nilai validitas konten seluruh butir item soal yaitu 0,804 pada kategori valid. 


\section{REFERENSI}

1. Rusilowati A. Asesmen Literasi Sains: Analisis Karakteristik Instrumen dan Kemampuan Siswa Menggunakan Teori Tes Modern Rasch Model. Pros Semin Nas Fis Univ Riau ke-3 2018;1-14.

2. OECD. PISA 2018 Results What Students Know And Can Do. 2019;I:1-254.

3. Fatmawati IN, Setiya U. Penerapan Levels Of Inquiry untuk Meningkatkan Literasi Sains Siswa SMP Tema Limbah dan Upaya Penanggulangannya. J Chem Inf Model 2015;7(2):151-9.

4. Odja AH, Payu CS. Analisis Kemampuan Awal Literasi Sains Siswa pada Konsep IPA. Pros Semin Nas Kim 2014;1(1):40-7.

5. Sujana A. Literasi Kimia Mahasiswa PGSD dan Guru IPA Sekolah Dasar pada Tema Udara. Mimb Sekol Dasar 2014;1(1):99-107.

6. Thummathong R, Thathong K. Chemical Literacy Levels of Engineering Students in Northeastern Thailand. Kasetsart J Soc Sci 2018;39(3):478-87.

7. Nisa A, Sudarmin, Samini. Efektivitas Penggunaan Modul Terintegrasi Etnosains dalam Pembelajaran Berbasis Masalah untuk Meningkatkan Literasi Sains Siswa. USEJ Unnes Sci Educ J 2015;4(3):1049-56.

8. Shwartz Y, Ben-Zvi R, Hofstein A. The use of scientific literacy taxonomy for assessing the development of chemical literacy among high-school students. Chem Educ Res Pract 2006;7(4):203-25.

9. Prastiwi MNB, Rahmah N, Khayati N, Utami DP, Primastuti M, Majid AN. Studi Kemampuan Literasi Kimia Peserta Didik pada Materi Elektrokimia. Pros Semin Nas Kim 2017;21:183-8.

10. Diana S, Rachmatulloh A, Rahmawati ES. Profil Kemampuan Literasi Sains Siswa SMA berdasarkan Instrumen Scientific Literacy Assesments (SLA). Pros Semin Nas XII Pendidik Biol FKIP UNS 2015;285-91.

11. Pakesa CM, Yusmaita E. Perancangan Assesmen Literasi Kimia pada Materi Laju Reaksi Kelas XI SMA / MA. EduKimia J 2019;1(4):84-9.

12. Afifah S, Yusmaita E. Perancangan Assesmen Literasi Kimia pada Materi Termokimia Kelas XI SMA / MA. EduKimia J 2019;1(4):79-83.

13. Islami AZ el, Permanasari A, Nahadi. Membangun Literasi Sains Siswa pada Konsep Asam Basa melalui Pembelajaran Inkuiri Terbimbing. J Penelit dan Pembelajaran IPA 2016;2(2):110-20.

14. Duit R, Gropengieber H, Kattmann U, Komorek M, Ilka Parchmann. The Model of Educational Reconstruction - A Framework for Improving Teaching and Learning Science. 2009;(1995):1-20.
15. Hendryadi. Content Validity (Validitas Isi). Teor Pers Pap 2014;01(01):1-5.

16. Hayat S. Asam Format. J Kim dan Kemasan 2017;24-8.

17. Phillips JS, Strozak VS, Wistrom C. Chemistry Concepts and Applications. 2002. page 1-911.

18. Arif I. Batu bara Indonesia. In: Gramedia pustaka utama. 2014. page xviii. 